Article

\title{
Service Climate and Empowerment for Customer Service Quality among Vietnamese Employees at Restaurants
}

\author{
Loan Pham Thi Phuong ${ }^{1}$ and Young-joo Ahn ${ }^{1,2, *}$ \\ 1 Department of Hospitality and Tourism Management, Sejong University, Seoul 05006, Korea; \\ ptloan1995@gmail.com \\ 2 Tourism Industry Data Analytics Lab (TIDAL), Department of Hospitality and Tourism Management, \\ Sejong University, Seoul 05006, Korea \\ * Correspondence: yjahn@sejong.ac.kr
}

Citation: Pham Thi Phuong, L.; Ahn, Y.-j. Service Climate and Empowerment for Customer Service Quality among Vietnamese

Employees at Restaurants.

Sustainability 2021, 13, 1172.

https://doi.org/10.3390/su13031172

Academic Editor: Mark A. Bonn

Received: 23 December 2020

Accepted: 20 January 2021

Published: 22 January 2021

Publisher's Note: MDPI stays neutral with regard to jurisdictional claims in published maps and institutional affiliations.

Copyright: (c) 2021 by the authors. Licensee MDPI, Basel, Switzerland. This article is an open access article distributed under the terms and conditions of the Creative Commons Attribution (CC BY) license (https:// creativecommons.org/licenses/by/ $4.0 /)$.

\begin{abstract}
This study examines the relationship between service climate, empowerment, and organizational citizenship behavior among Vietnamese employees at restaurants in urban areas of South Korea. Moreover, the mediating role of empowerment between service climate and organizational citizenship behavior is investigated. From a sample of 209 Vietnamese respondents working in Asian ethnic restaurants, the findings indicate that work facilitation is the most influential service climate that affects empowerment. However, two service climate factors-managerial support and customer orientation - are not statistically significant. Moreover, organizational citizenship behavior among employees is enhanced not only by service climate but also by empowerment. This study provides empirical evidence of employee perceptions of service climate and of the influence of service climate on employee empowerment and organizational citizenship behavior for customer service quality. This study expands the knowledge regarding foreign employees at restaurants and provides important theoretical and practical implications for creating a sustainable work environment and empowering employees who strive for an excellent quality of customer service in the context of the restaurant industry.
\end{abstract}

Keywords: restaurant; Vietnamese employees; service climate; empowerment; organizational citizenship behavior; urban areas

\section{Introduction}

The number of foreign workers in the Republic of Korea has increased since the 1960s. As the growth of industries has rapidly increased, labor shortage has become a serious social problem [1,2]. The labor shortage results in low birth rate, high education level, and difficult and dangerous work avoidance in South Korea [1]. For this reason, the Ministry of Employment and Labor (MOEL) introduced the foreign workforce quota to solve the labor shortage and balance human resource supply and demand for the affected industries [1]. Legally employed foreign workers have become an important human resource, particularly for small- and medium-sized enterprises (SMEs) [1,2]. According to the Ministry of Justice (MOJ) [2], South Korea has approximately 2.14 million foreign workers from China (44.2\%), Vietnam (10.1\%), Thailand (8.9\%), the United States $(6.9 \%)$, and Uzbekistan (3.3\%). However, other social problems related to foreign workers have emerged. Companies hiring foreign workers have reported negative aspects such as employee job stress, high turnover intention, conflicts between employees and owners, cultural differences, and communication problems $[3,4]$.

In hospitality and tourism, employee service quality is one of the critical components for customer satisfaction and loyalty. The intangible service quality of employees can fulfill customer needs and desires and reduce the gap between customer expectations and service quality performance [5,6]. Furthermore, service quality can become a core competency and create a unique brand image that leads to strong competitiveness in hospitality 
and tourism [7-9]. As companies in hospitality and tourism seek growth through attracting international tourists, diversifying the travel market, and facilitating international cooperation and exchange, managing a multicultural workforce is essential [10,11].

Given that most companies in hospitality and tourism are micro- and small-sized enterprises, many foreign workers are employed in this industry in South Korea. However, limited research has focused on foreign workers with the aim of understanding their work environment, creating a sustainable workplace, and facilitating quality of service for customers. As a result, research on leadership and work environment for foreign workers and employees with different cultural backgrounds, and the creation of a sustainable work environment is necessary $[4,12]$. The present study focuses on the restaurant industry, which is service intensive. The success of restaurants mainly depends on the efficiency of human resource management and employee understanding of organizational operations and intangible service delivery $[6,13,14]$.

In this regard, the service climate can become a useful theoretical framework $[15,16]$. Perceived customer orientation, interaction with managers, and rewards and recognition in the workplace are closely associated with employee commitment and outstanding performance [17]. Furthermore, understanding the mediating role of empowerment between service climate and organizational citizenship behavior (OCB) expands the knowledge on how to create a better work environment for employees and achieve their high service quality for customer satisfaction and loyalty $[18,19]$. Although the relationships between critical factors and $\mathrm{OCB}$, such as psychological attachment, commitment, and job satisfaction, have been explored [20], identifying the important factors that are closely associated with OCB among employees, especially those with different cultural backgrounds, is necessary [21].

Therefore, the purpose of this study examines the relationships among service climate, empowerment, and OCB among Vietnamese employees of restaurants in South Korea. The mediating role of empowerment between service climate and OCB is also examined. This study provides empirical evidence of employee perceptions of service climate and of the influence of service climate on employee empowerment and OCB for customer service delivery. In addition, this study expands the knowledge of foreign employees at restaurants and provides important theoretical and practical implications for creating a sustainable work environment and empowering employees who strive for a high quality of customer service in the context of the restaurant industry.

\section{Literature Review}

\subsection{Service Climate}

The number of studies on service climate in hospitality and tourism is increasing [14,22-29]. Service climate is defined as "employee perceptions of the practices, procedures, and behaviors that get rewarded, supported, and expected with regard to customer service and customer service quality" (Schneider, White, and Paul [16], p. 151).

Previous studies on service climate have used different dimensions of service climate, with no consensus regarding service climate dimensions $[12,16,30,31]$. Research on service climate $[26,27]$ has mainly used three dimensions of service climate, namely, customer orientation, managerial support, and work facilitation [15,16,31].

Customer orientation refers to the vision and goals of an organization to deliver excellent services to customers and fulfill their needs and wants [15]. Managerial support refers to supervisor support, advice, and employee training to learn their organization's service priorities and visions for customer service excellence [16]. Finally, work facilitation refers to rewards and recognition from the organization when employees make efforts to provide excellent service and exhibit behaviors aimed at achieving the priorities of their organization [15].

In the context of the hotel industry, employees have been found to perceive the service climate. When organizations value higher quality of services for customers, frontline employees are likely to provide high service quality for customers [19,24,26-29,32]. Recently, Kang and Busser [27] examined the relationships among service climate, psychological 
capital, employee engagement, and turnover intention in the hotel industry. Employees who perceived the service climate were inclined to place the organization's priorities first and showed higher job satisfaction.

Studies on service climate in the restaurant industry are few and necessary $[14,25,30]$. Previous research on service climate in restaurants has focused on sustainable service management in restaurants [25,30] and customer orientation and training [14]. Although emerging studies examine the antecedents and outcomes of service climate and employee perceptions behaviors based on social exchange theory [27], limited empirical evidence exists for service climate and customer service practices among frontline employees in the context of the restaurant industry.

\subsection{Service Climate and Empowerment}

Empowerment refers to motivational behaviors among employees that competently fulfill their work role [33,34]. Spreitzer [33] proposed multiple dimensions of empowerment based on the conceptual model developed by Thomas and Velthouse [35]. Psychological empowerment has four dimensions, namely, impact, competence, meaningfulness, and self-determination [33]. Impact refers to "the degree to which behavior is seen as 'making a difference' in terms of accomplishing the purpose of the task, that is producing the intended effects in one's task environment" (Thomas and Velthouse [35], p. 672). Competence refers to workers' feeling of capability to fulfill their work role [36]. Meaningfulness refers to employees' personal values and visions that match the organizational visions and work goals [33]. Finally, self-determination refers to intrinsically motivated actions when employees make decisions [33,34].

These multiple dimensions of empowerment have previously been demonstrated [33]. At restaurants, the four dimensions may not be assessed equally, because high efficiency and standardized operations are emphasized, leading to lower self-determination among employees [21]. In this regard, the present study focuses on impact among the four psychological empowerment dimensions [33,34]. Impact is related to the locus of control and is an opposed concept to learned helplessness and powerlessness when employees perform their work role [33,34]. The concept of impact measures the extent to which employees can control organizational procedures and act proactively at their workplace to obtain positive outcomes [37]. Empowered employees are more likely to be involved in their work actively and show a higher level of ownership [34]. As a result, given that hospitality and tourism require intensive human service for customers, empowering employees is one of the critical issues for organizational performance $[13,38,39]$.

Organizational management style influences employees' empowerment and job performance $[13,21]$. However, strict organizational regulations and job manuals may constrain frontline workers' sense of control, preventing them from providing different services from the standard service procedures [21]. Support from colleagues, direct managers and supervisors can increase a sense of control. Employees tend to build trust with managers and actively participate in building strategies and improving managerial procedures efficiently [34]. Spreitzer [33] indicated that rewards, incentives, and recognition of employee contributions to their organizations are important components for empowerment.

However, the direct relationships between three dimensions of service climate and empowerment have rarely been explored in hospitality and tourism. He, $\mathrm{Li}$, and Lai [26] called for further research to explore the mediators and outcomes of service climate in different contexts of hospitality and tourism. In addition, the critical antecedents and consequences of empowerment among employees with different cultural backgrounds at restaurants are rarely examined. Therefore, this present study explores the relationship between service climate and empowerment among Vietnamese employees in the restaurant industry. Based on the previous literature, following hypotheses are proposed:

Hypothesis 1 (H1). Customer orientation has a positive effect on empowerment.

Hypothesis 2 (H2). Managerial support has a positive effect on empowerment. 
Hypothesis 3 (H3). Work facilitation has a positive effect on empowerment.

\subsection{Customer Orientation and $O C B$}

OCB is defined as "individual behavior that is discretionary, not directly or explicitly recognized by the formal reward system, and that in the aggregate promotes the effective functioning of the organization" (Organ, [40], p. 4). OCB has been widely conceptualized and provides empirical evidence of its antecedents and the outcomes of employee OCB [41-44]. The major advantages of OCB include increasing employee productivity and overall organization performance, helping colleagues, sharing resources for better work performance, and proactively participating in meetings in order to solve problems in their organizations $[41,44]$. Moreover, employees' extra efforts with respect to the provision of excellent service beyond that required by their work role increase the competitiveness of their organization, as well as customer satisfaction and loyalty [41]. The role of OCB among service providers and consumers in hospitality and tourism has also been explored [45-49]. Furthermore, the restaurant industry is showing increased interest in the antecedents and consequences of OCB $[20,46,50,51]$.

In particular, the number of studies on the relationship between customer orientation and OCB is increasing $[18,47,52]$. When employees perceive that their organization is focused on customer orientation and excellence service, they have a sense of obligation. As a result, they fulfill their required work roles and are also willing to provide extrarole service behaviors for customers [18]. Based on the literature review, the following hypothesis is proposed:

Hypothesis 4 (H4). Customer orientation has a positive effect on $O C B$.

\subsection{Empowerment and Organizational Citizenship Behavior}

Frontline employees are the primary contact point with customers [53]. Employees' OCB increases customer perception of service quality and increases customer satisfaction [33]. Several studies have explored the relationship between empowerment and OCB, showing that empowerment is positively related to OCB [18,33]. Spreitzer [33] indicated that one of the positive outcomes of empowered employees is their OCB. For example, Chiang and Hsieh [18] examined the relationship between empowerment and employee citizenship behaviors in hotels, and the results indicate that empowerment positively influenced OCB. Without empowerment, employees may feel helpless and have insufficient power when making the decision to provide customer-oriented services beyond work requirements. Therefore, the following hypothesis is proposed:

Hypothesis 5 (H5). Empowerment positively influences OCB.

\section{Method}

\subsection{Vietnamese Employees in South Korea}

The central government of South Korea introduced the Industrial Trainee Scheme (ITS) in 1994 in an attempt to improve programs for foreign workers. The Ministry of Employment and Labor (MOEL) launched the Employment Permit system (EPS) in 2003 [54]. The objectives of the EPS were to solve the lack of labor and provide a supply of human resources for balanced development and to sustainably manage foreign workers [54]. The EPS operates based on bilateral government-to-government memoranda of understanding (MOU) with 15 countries, including those shown in Table 1 . Approximately 188,000 foreign workers were EPS E-9 visa holders in 2012 [2]. Subsequently, the EPS set the quota for E-9 Workers to 57,000. According to the EPS, a significant proportion of foreign workers in Seoul and Gyeonggi province were from Vietnam, Thailand, the Philippines, Indonesia, Sri Lanka and Mongolia, excluding those from China (e.g., Korean Chinese) [1]. Vietnamese employees ranked second in number, and most of them worked in urban areas near the 
capital city, Seoul. Therefore, this study focuses on Vietnamese employees in urban areas in the restaurant industry.

Table 1. Top ten nationalities for long-term foreign stay in South Korea.

\begin{tabular}{cccccc}
\hline Nationality & $\mathbf{2 0 1 6}$ & $\mathbf{2 0 1 7}$ & $\mathbf{2 0 1 8}$ & $\mathbf{2 0 1 9}$ & June 2020 \\
\hline China & $1,016,607$ & $1,018,074$ & $1,070,566$ & $1,101,782$ & 943,540 \\
Vietnam & 149,384 & 169,738 & 196,633 & 224,518 & 214,774 \\
Thailand & 100,860 & 153,259 & 197,764 & 209,909 & 189,249 \\
America & 140,222 & 143,568 & 151,018 & 156,982 & 146,608 \\
Uzbekistan & 54,490 & 62,870 & 68,433 & 75,320 & 71,329 \\
Russia & 32,372 & 44,851 & 54,064 & 61,427 & 53,907 \\
Philippines & 56,980 & 58,480 & 60,139 & 62,398 & 53,416 \\
Mongolia & 35,206 & 45,744 & 46,286 & 48,185 & 46,339 \\
Cambodia & 45,832 & 47,105 & 47,012 & 47,565 & 43,378 \\
Nepal & 34,108 & 36,627 & 40,456 & 42,781 & 41,971 \\
\hline Total (n) & $2,049,441$ & $2,180,498$ & $2,367,607$ & $2,524,656$ & $2,135,689$ \\
\hline
\end{tabular}

Note: more than 14 nationalities are not listed in this table; source: Ministry of Justice (2020). Immigration/stay guide.

\subsection{Measures}

The questionnaire consisted of three sections. The first section included the characteristics of restaurant employees (e.g., restaurant type, position, employee type). The second section included items related to service climate, empowerment, and citizenship behavior. These constructs were employed to examine the proposed model (see Figure 1). Finally, the third and final section included demographic information.

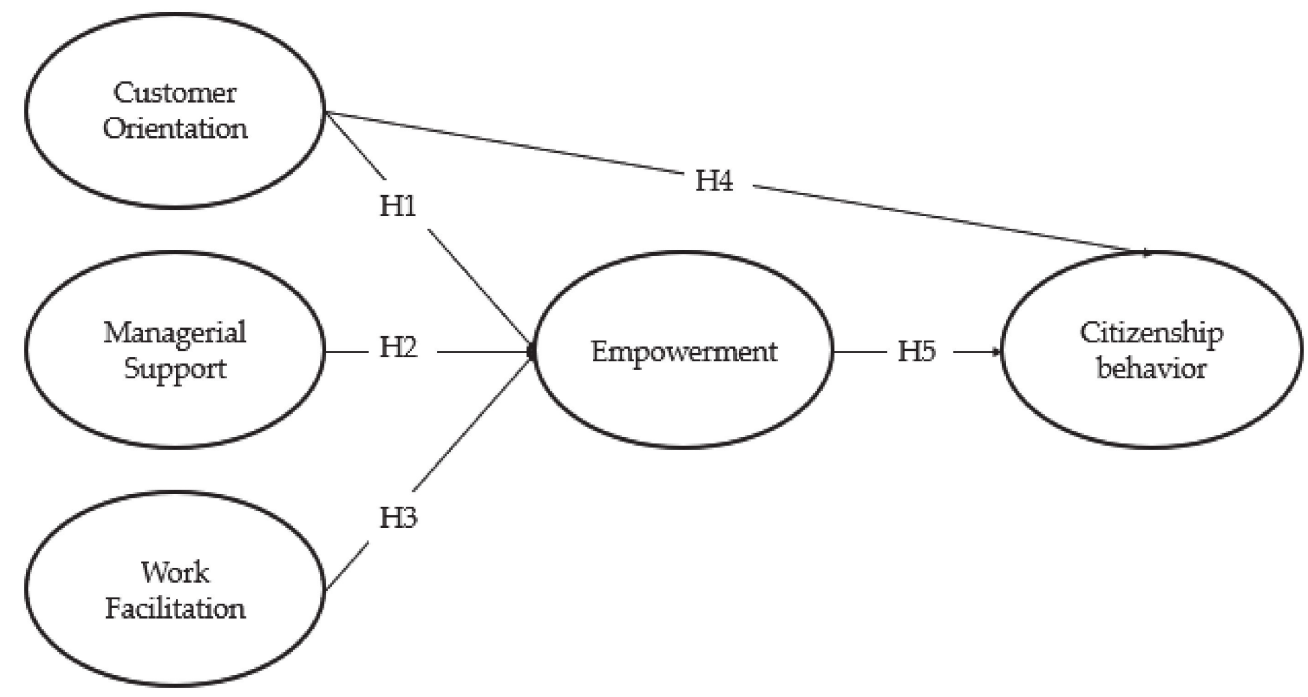

Figure 1. The proposed study model.

Measurements of service climate were adopted from previous studies [16,26]. A total of 14 items were employed to measure three constructs of service climate, namely, customer orientation, managerial support, and work facilitation [16,26]. Customer orientation included six items (e.g., "My restaurant has clear ideas about customers and their needs") [16,26]. Managerial support included four items (e.g., "My direct manager encourages me to deliver high quality service") [16,26]. Work facilitation included four items (e.g., "I received adequate support from workmates to do my job well") [16,26]. The measurement of empowerment was similarly adopted from previous studies [33]. Empowerment included three items (e.g., "My opinion counts in work group decision making"). Organizational citizenship behavior includes four items (e.g., "I voluntarily assist customers even if it means going beyond the requirement of my job") $[55,56]$. All of the second part was 
measured using a 5 -point Likert-type scale $(1=$ strongly disagree to $5=$ strongly agree $)$. Finally, the last page of the research questionnaire included demographic information.

\subsection{Data Collection}

The target participants were Vietnamese employees working in Asian ethnic restaurants in Seoul, South Korea. This study used respondent-driven sampling (RDS) [57]. The criteria for participation in this study were: (1) those who are Vietnamese living in South Korea; (2) those who currently worked as a part- or full-time employee at a restaurant in South Korea; and (3) those who were aged over 18 years. To reach this population, the research team contacted owners and Vietnamese employees of Asian ethnic restaurants and asked for participation in this study. In addition, the online survey link was posted on popular online communities for Vietnamese people living in South Korea.

A cover letter was included with the online survey to introduce this study's aim and objectives. After completing the questionnaire, a pilot test was conducted with experts and graduate student majoring in Hospitality and Tourism Management to check the survey items for typos and flaws. After completion of the pilot test, the questionnaire was revised and refined for clarification of the items. Initially, the survey items were developed in English. After checking the face and content validity, all items were translated into Vietnamese. The finalized measurement was examined for face validity and content validity.

The online survey was created using the SurveyMonkey website. All respondents voluntarily participated in this study. The survey link was sent via email, Facebook messages, social media links, and weblink. A reminder email was sent to those who did not complete the survey. Data collection procedures were completed between October 2019 to January 2020. Responses were received from 252 participants, and excluding those that were incomplete or were from employees of a different nationality, a total of 209 surveys were obtained from Vietnamese respondents working in Asian ethnic restaurants.

\subsection{Demographic Characteristics}

Table 2 presents the frequency and percentage of the demographic characteristics. In terms of gender, the number of female respondents $(n=120,57.4 \%)$ was higher than that of male respondents $(n=89,42.6 \%)$. The largest age group was 18-24 years old $(n=105$, $50.2 \%)$ followed by $25-29$ years old $(n=79,37.8 \%)$, and $30-34$ years old $(n=18,8.6 \%)$. Most respondents reported that they had a bachelor's degree $(n=127,60.8 \%)$, followed by had graduated high school $(\mathrm{n}=39,18.7 \%)$ and had a post-graduate degree $(\mathrm{n}=26$, $12.4 \%)$. A majority of them were part-time employees $(n=149,71.3 \%)$. Regarding marital status, a majority of respondents were single $(n=175,83.7 \%)$. Approximately $45.9 \%$ of the respondents $(\mathrm{n}=96)$ reported that their monthly income was under 2,000,000 Korean Won (KRW), followed by from KRW 2,000,000 to 4,000,000 ( $\mathrm{n}=61,29.2 \%)$. The respondents work experience varied. Approximately $34.9 \%$ of the respondents $(n=73)$ reported that they had worked for less than three months in the restaurant and food service industry. In addition, $30.6 \%$ of them $(n=64)$ reported that they had worked in the industry for 3 to 12 months, and $28.2 \%$ of them $(n=59)$ had worked for 1 to 3 years. 
Table 2. Demographic characteristics.

\begin{tabular}{|c|c|c|c|}
\hline Variable & Category & $\mathbf{n}$ & $\%$ \\
\hline \multirow{2}{*}{ Gender } & Male & 89 & 42.6 \\
\hline & Female & 120 & 57.4 \\
\hline \multirow{5}{*}{ Age $(M=24.5)$} & 18-24 years old & 105 & 50.2 \\
\hline & 25-29 years old & 79 & 37.8 \\
\hline & 30-34 years old & 18 & 8.6 \\
\hline & 35-39 years old & 5 & 2.4 \\
\hline & Over 40 years old & 2 & 1.0 \\
\hline \multirow{4}{*}{ Education } & High school & 39 & 18.7 \\
\hline & Associate degree & 17 & 8.1 \\
\hline & Bachelor's degree & 127 & 60.8 \\
\hline & Post-graduate degree & 26 & 12.4 \\
\hline \multirow{2}{*}{ Occupation type } & Full-time & 60 & 28.7 \\
\hline & Part-time & 149 & 71.3 \\
\hline \multirow{3}{*}{ Marital status } & Single & 175 & 83.7 \\
\hline & Married & 29 & 13.9 \\
\hline & Other & 5 & 2.4 \\
\hline \multirow{5}{*}{ Monthly Income } & Less than 2,000,000 Korean Won & 96 & 45.9 \\
\hline & 2,000,000-less than $4,000,000$ & 61 & 29.2 \\
\hline & $4,000,000$-less than $6,000,000$ & 29 & 13.9 \\
\hline & $6,000,000-$ less than $8,000,000$ & 11 & 5.3 \\
\hline & Over $8,000,000$ & 12 & 5.7 \\
\hline \multirow{5}{*}{$\begin{array}{l}\text { Working experience } \\
\text { in restaurant and } \\
\text { food service industry }\end{array}$} & less than 3 months & 73 & 34.9 \\
\hline & 3 months-less than 12 months & 64 & 30.6 \\
\hline & 1 year-less than 3 years & 59 & 28.2 \\
\hline & 3 years-less than 5 years & 10 & 4.8 \\
\hline & More than 5 years & 3 & 1.4 \\
\hline
\end{tabular}

${ }^{*}$ USD $\$ 1$ is equivalent to 1093 Korean Won (KRW).

\section{Results}

\subsection{The Results of Confirmatory Factor Analysis (CFA)}

This study followed a two-stage approach [58]. The five hypotheses of the proposed model were examined. Factor analyses such as exploratory factor analysis (EFA) and CFA were used to assess the validity and reliability of the constructs. After confirming that the model fit, the structural equation model (SEM) was used to examine the relationships among the five hypotheses. Stata 16 was used for analysis. As shown in Tables 3 and 4, the results of CFA showed standardized loadings ranging from 0.54 to 0.85 . The CFA results showed that the overall model fit with statistically acceptable values: $\chi 2(67)=129.97$, $p<0.001, \chi 2 / \mathrm{df}=1.940 ; \mathrm{CFI}=0.942 ; \mathrm{TLI}=0.922 ; \mathrm{RMSEA}=0.067$. The overall model fit shows satisfactory fit indices $[59,60]$. The composite reliability ranged from 0.649 to 0.805 . Other than citizenship behavior, the other constructs exceeded the threshold of 0.7 [61]. The results of the composite reliability indicated the internal consistency of the items. The average variance extracted (AVE) exceeded 0.50 for the proposed constructs [62], except for OCB, which had an AVE value of 0.380. Despite this one construct having an AVE less than $0.5, C R$ was above the acceptable level of 0.6 [61]. The findings showed convergent validity [63]. Moreover, discriminant validity was evaluated using CFA, by calculating the squared correlation between dimensions and the AVE in the measurement model. As presented Table 4, all squared correlations between two factors have lower levels than the AVE of all factors. As a result, discriminant validity was confirmed in the standardized correlation matrix. 
Table 3. Confirmatory factor analysis: items and loadings.

\begin{tabular}{|c|c|}
\hline Item & Standardized Loading \\
\hline \multicolumn{2}{|l|}{ Service climate } \\
\hline \multicolumn{2}{|l|}{ Customer orientation } \\
\hline My restaurant has clear ideas about customers and their needs $[16,26]$. & 0.85 \\
\hline $\begin{array}{l}\text { High quality service is emphasized as the best way to keep customers in my } \\
\text { restaurant }[16,26] \text {. }\end{array}$ & 0.72 \\
\hline $\begin{array}{l}\text { My restaurant does a good job of keeping customers informed of changes, } \\
\text { which affect them }[16,26] .\end{array}$ & 0.72 \\
\hline \multicolumn{2}{|l|}{ Managerial support } \\
\hline My direct manager encourages me to deliver high quality service $[16,26]$. & 0.84 \\
\hline My manager is responsive to my requests for help or guidance $[16,26]$. & 0.72 \\
\hline $\begin{array}{l}\text { My manager is very committed to improving the quality of our area's work and } \\
\text { service }[16,26] .\end{array}$ & 0.64 \\
\hline \multicolumn{2}{|l|}{ Work facilitation } \\
\hline I receive adequate support from workmates to do my job well $[16,26]$. & 0.76 \\
\hline If I perform job well, I receive appropriate recognition and reward $[16,26]$. & 0.80 \\
\hline \multicolumn{2}{|l|}{ Empowerment } \\
\hline My opinion counts in work group decision making [33]. & 0.76 \\
\hline I have a great deal of control over my job [33]. & 0.71 \\
\hline I have influence over what happens in my work group [33]. & 0.74 \\
\hline \multicolumn{2}{|l|}{ Organizational citizenship behavior } \\
\hline $\begin{array}{l}\text { I voluntarily assist customers even if it means going beyond the requirements of } \\
\text { my job }[55,56] .\end{array}$ & 0.64 \\
\hline $\begin{array}{l}\text { I help customers with problems beyond what is expected or required of me } \\
\qquad[55,56] .\end{array}$ & 0.54 \\
\hline I often go above and beyond the call of duty when serving customers $[55,56]$. & 0.66 \\
\hline
\end{tabular}

Table 4. Summary of the CFA results.

\begin{tabular}{ccccccccc}
\hline & $\begin{array}{c}\text { No. of } \\
\text { Items }\end{array}$ & $\begin{array}{c}\text { Mean } \\
\text { (Std dev.) }\end{array}$ & AVE & CO & MS & WF & EM & OCB \\
\hline Customer orientation (CO) & 3 & $3.534(0.833)$ & 0.586 & $0.805^{\mathrm{a}}$ & $0.496^{\mathrm{b}}$ & 0.394 & 0.262 & 0.272 \\
Managerial support (MS) & 3 & $3.638(0.757)$ & 0.545 & $0.246^{\mathrm{c}}$ & 0.779 & 0.403 & 0.288 & 0.260 \\
Work facilitation (WF) & 2 & $3.579(0.813)$ & 0.609 & 0.155 & 0.162 & 0.752 & 0.282 & 0.233 \\
$\begin{array}{c}\text { Empowerment (EM) } \\
\text { Organizational citizenship } \\
\text { behavior (OCB) }\end{array}$ & 3 & $3.418(0.753)$ & 0.543 & 0.067 & 0.083 & 0.080 & 0.785 & 0.200 \\
& $3.466(0.660)$ & 0.380 & 0.074 & 0.068 & 0.054 & 0.04 & 0.649 \\
\hline
\end{tabular}

Goodness-of-fit statistics: Note: $\chi 2(67)=129.97, p<0.001 \chi 2 / \mathrm{df}=1.940 ;$ CFI $=0.942$; TLI = 0.922; RMSEA $=0.067 ;$ SRMR $=0.049$. AVE $=$ average variance extracted $; \mathrm{CFI}=$ comparative fit index; $\mathrm{TLI}=$ Tucker - Lewis index; RMSEA = root mean square error of approximation; SRMR = standardized root mean squared residual; ${ }^{a}$ Composite reliability are along the diagonal; ${ }^{\mathrm{b}}$ Correlations; ${ }^{\mathrm{c}}$ Squared correlations.

\subsection{Structural Model}

SEM was conducted to test the hypothesis. The fit indices of the SEM results in Table 5 show an acceptable fit $\left(\chi^{2}=135.195, d f=69, \chi^{2} / d f=1.959\right.$, RMSEA $=0.068, \mathrm{CFI}=0.940$, $\mathrm{TLI}=0.920$, SRMR $=0.053)[59,60]$. The results showed that work facilitation $(\beta=0.378$, $p<0.01)$ was significantly related to empowerment. Customer orientation $(\beta=0.323$, $p<0.001)$ was significantly related to citizenship behavior. Empowerment $(\beta=0.251$, $p<0.001$ ) was significantly related to citizenship behavior. However, customer orientation ( $\beta=-0.02, p=0.839)$ and managerial support $(\beta=0.258, p=0.072)$ were not significantly associated with empowerment. These results supported $\mathrm{H} 3, \mathrm{H} 4$, and $\mathrm{H} 5$, but not $\mathrm{H} 1 \mathrm{Or} \mathrm{H} 2$ (see Figure 2). The results provided support for the hypothesis that customer orientation has positive effects on the facilitation of citizenship behavior. In addition, work facilitation 
has a positive relationship to citizenship behavior mediated by empowerment. The results provided support for $\mathrm{H} 5$ and emphasized empowerment as an important mediator with a positive effect on citizenship behavior in the proposed model.

Table 5. The SEM results.

\begin{tabular}{|c|c|c|c|c|c|c|}
\hline & & & & Coefficient & $\mathbf{z}$ & Hypothesis \\
\hline $\mathrm{H} 1$ & $\begin{array}{c}\text { Customer } \\
\text { orientation }\end{array}$ & $\rightarrow$ & Empowerment & -0.020 & -0.20 & Not supported \\
\hline $\mathrm{H} 2$ & Managerial support & $\rightarrow$ & Empowerment & 0.258 & 1.80 & Not supported \\
\hline $\mathrm{H} 3$ & Work facilitation & $\rightarrow$ & Empowerment & $0.378^{* *}$ & 2.69 & Supported \\
\hline $\mathrm{H} 4$ & $\begin{array}{l}\text { Customer } \\
\text { orientation }\end{array}$ & $\rightarrow$ & $\begin{array}{l}\text { Organizational } \\
\text { citizenship } \\
\text { behavior }\end{array}$ & $0.323^{* * *}$ & 3.58 & Supported \\
\hline H5 & Empowerment & $\rightarrow$ & $\begin{array}{l}\text { Organizational } \\
\text { citizenship } \\
\text { behavior }\end{array}$ & $0.251^{* * *}$ & 4.00 & Supported \\
\hline
\end{tabular}

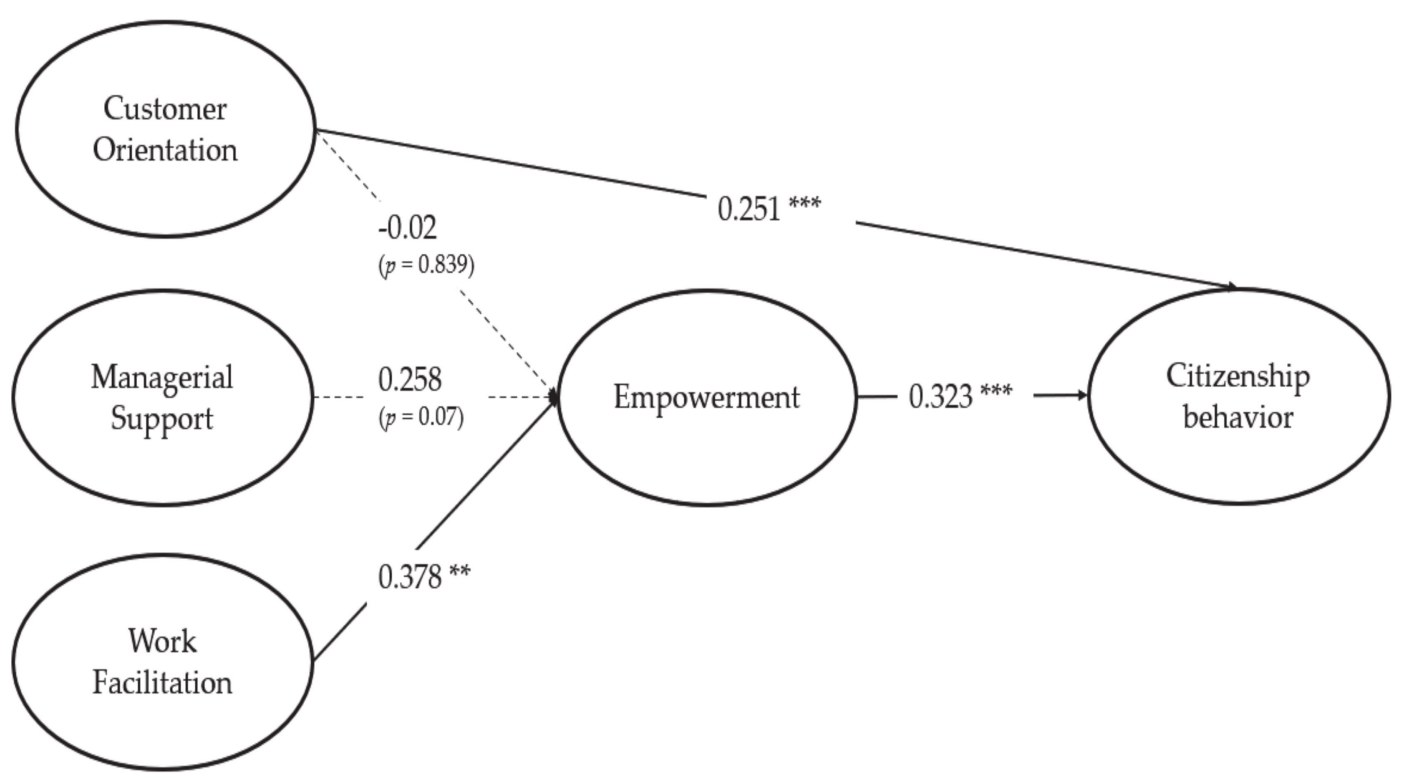

Figure 2. The path coefficients of the proposed model. Note: ${ }^{*} p=<0.05,{ }^{* *} p=<0.01,{ }^{* * *} p=<0.001$.

The mediating effects were analyzed. As presented in Table 6, the mediating role of empowerment between work facilitation and citizenship behavior were confirmed. The results indicated that the indirect effect was statistically significant, supporting $\mathrm{H} 3$. Empowerment seemed to fully mediate the relationship between work facilitation and citizenship behavior, with a significant indirect effect of constructs $(p<0.001)$. However, customer orientation and managerial support were not statistically significant, and the confidence interval included zero points. 
Table 6. The direct, indirect, and total effect of the proposed model.

\begin{tabular}{|c|c|c|c|c|c|}
\hline & & & Estimate & S.E. & $p$ \\
\hline $\begin{array}{l}\text { Customer } \\
\text { orientation }\end{array}$ & $\rightarrow$ & Empowerment & -0.020 & 0.099 & 0.839 \\
\hline Managerial support & $\rightarrow$ & Empowerment & 0.258 & 0.143 & 0.072 \\
\hline Work facilitation & $\rightarrow$ & Empowerment & 0.378 & 0.141 & 0.007 \\
\hline $\begin{array}{c}\text { Customer } \\
\text { orientation }\end{array}$ & $\rightarrow$ & $\begin{array}{c}\text { Organizational } \\
\text { citizenship behavior }\end{array}$ & -0.007 & 0.032 & 0.840 \\
\hline Managerial support & $\rightarrow$ & $\begin{array}{c}\text { Organizational } \\
\text { citizenship behavior }\end{array}$ & 0.083 & 0.526 & 0.113 \\
\hline Work facilitation & $\rightarrow$ & $\begin{array}{c}\text { Organizational } \\
\text { citizenship behavior }\end{array}$ & 0.122 & 0.055 & 0.026 \\
\hline $\begin{array}{l}\text { Customer } \\
\text { orientation }\end{array}$ & $\rightarrow$ & $\begin{array}{c}\text { Organizational } \\
\text { citizenship behavior }\end{array}$ & 0.251 & 0.063 & 0.000 \\
\hline Empowerment & $\rightarrow$ & $\begin{array}{l}\text { Organizational } \\
\text { citizenship behavior }\end{array}$ & 0.323 & 0.090 & 0.000 \\
\hline
\end{tabular}

\section{Discussion and Conclusions}

\subsection{Theoretical Implications}

The present study focuses on the relationships between service climate, empowerment, and OCB among Vietnamese employees at restaurants in South Korea. This study provides empirical evidence that OCB among employees is enhanced not only by service climate, but also by empowerment. Service climate increases empowerment and enhances OCB. Regarding service climate, the results reveal three factors of service climate: customer orientation, managerial support, and work facilitation [15,16].

The present study demonstrates the mediating role of empowerment and suggest a critical factor related to service climate, thereby enriching the previous literature in hospitality and tourism [26]. The empirical findings indicate that work facilitation is the most influential service climate that affects empowerment. However, two factors of managerial support and customer orientation are not statistically significant. Employees with rewards and recognition are likely to be empowered. Rewards and recognition can serve as an important signal for perceiving organizational benefits and valued actions among employees at restaurants.

The relationship between managerial support and empowerment is not statistically significant ( $\beta=0.258, p=0.072$ ). This study rejects this hypothesis. However, the interpretation of this result might depend on the $p$-value criteria. Given the small number of studies on the relationship between the three constructs of service climate and empowerment, further research should examine the relationship between managerial support and empowerment.

One of the important findings is that customer orientation does not significantly influence empowerment, similar to its insignificant relationship with employee psychological factors such as commitment $[26,29]$. A possible reason for this is that customer orientation emphasizes standardized operational procedures and provides training programs for employees. Therefore, customer orientation would be effective when companies increase the efficiency of employees by enhancing their understanding of standardized organizational operations and service processes. However, these training programs may neither increase the sense of control nor facilitate empowerment among employees.

The results indicate that empowerment positively influences $\mathrm{OCB}$, which is consistent with previous research $[13,18,33]$. Employees that are empowered in their work role are likely to help others, be willing to show extra-role behavior for customers, and deliver excellent service to customers at restaurants. This study empirically demonstrates that highly empowered employees with different cultural backgrounds show OCB in the restaurant industry.

Furthermore, the results highlight the mediating role of empowerment in the context of restaurants and provide empirical evidence. The literature related to internal marketing 
and employee service quality for increasing customer satisfaction can be enriched. This study suggests that employees have multidimensional service climate factors. Employees' service climate has previously been explored in luxury hotels and major companies. This study extends the Vietnamese employee service climate with respect to the restaurant industry and the empowerment associated with OCB.

\subsection{Practical Implications}

The findings of this study suggest important practical implications. One of the important findings is that empowerment is enhanced by work facilitation, indicating the need for rewards and recognition from managers to empower employees. For example, managers need to consider having events for their employees to provide tangible rewards and psychological recognitions for sharing information about employees' valued service performance for customers. In addition, managers need to provide the desired benefits and work facilitation for their employees.

Work facilitation is essential to understanding the reason for employees' willingness to perform extra-role tasks for customers. Matching rewards and recognition when developing employee performance evaluation programs and events can increase employee empowerment, because work facilitation is offered to employees who are devoted to excellent service delivery. To increase empowerment among frontline employees, restaurant owners and managers should appreciate employee contributions towards the provision of excellent service, as well as their autonomous decision making with respect to innovative service delivery. Moreover, the respondents in this study belonged to a relatively young age group, and managers should be aware of the differences between generational cohorts [64].

However, managerial support does not strongly influence empowerment. Managers need to provide sufficient instructions for customer service and provide employees with opportunities to make their own decisions in order to provide a high quality of customer service. In this way, empowerment level among frontline employees can be increased. Restaurant managers need to develop effective human resource management strategies. Moreover, maintaining an autonomous atmosphere that allows employees to understand customer service and restaurant operations is essential.

Customer orientation shows a direct relationship with OCB. Managers need to provide training programs for employees and increase their understanding of customer orientation. For example, managers could consider recruiting Vietnamese employees who understand the organizational culture and are willing to learn customer orientation and the vision of the restaurant.

Finally, the results suggest that empowerment affects OCB. Employees reporting high levels of empowerment are likely to engage in extra-role behavior in order to provide better customer service. Employees display their OCB for customers. With respect to customer orientation, employees need to learn the visions and goals of their organization. Therefore, managers should seek effective ways to recruit highly qualified employees that are willing to learn customer orientation. Moreover, managers need to provide signals regarding their desired employee behaviors through various empowering events that increase OCB at restaurants.

\subsection{Limitations and Recommendations for Future Research}

This study provides important empirical evidence, but also has several limitations. First, this study collects data from Vietnamese workers in South Korea in the context of the restaurant industry. The results cannot be generalized, and the proposed model needs to be replicated in different contexts related to hospitality and tourism. Further research needs to carry out a cross cultural research among multicultural workforce groups, and should be conducted by using different methods (e.g., experimental research, qualitative research). Second, this study utilizes cross-sectional data and cannot capture the longitudinal effects of the service climate on empowerment and citizenship behavior. The longitudinal study of these relationships can be used for further investigation. Third, this study focuses on one 
dimension of empowerment. Future studies using multiple dimensions of empowerment could enrich the mediating role between service climate and citizenship behavior. Finally, this study does not have statistically significant results of a multigroup analysis (e.g., gender, part time and full time). Future research needs to examine the moderating role in the proposed model.

Author Contributions: Conceptualization, Y.-j.A. and L.P.T.P.; methodology, L.P.T.P.; formal analysis, Y.-j.A.; data curation, L.P.T.P.; writing—original draft preparation, L.P.T.P.; writing—review and editing, L.P.T.P., Y.-j.A.; supervision, Y.-j.A. All authors have read and agreed to the published version of the manuscript.

Funding: This research received no external funding.

Institutional Review Board Statement: Not applicable.

Informed Consent Statement: Not applicable.

Data Availability Statement: Not applicable.

Conflicts of Interest: The authors declare no conflict of interest.

\section{References}

1. EPS Employment Permit System. Available online: https://www.eps.go.kr/eo/EmployPerSystem.eo?tabGb=01 (accessed on 23 December 2020).

2. MOJ Korea Immigration Service. Available online: https://www.immigration.go.kr:443/immigration/1569/subview.do? (accessed on 23 December 2020).

3. Kim, J.; Park, K. Demographic Policies against Aging in OECD Countries. SSRN Electron. J. 2017. [CrossRef]

4. Park, J.; Yoon, D.-Y.; Chang, J.W. The Effects of Authentic Leadership on Turnover Intention of Foreign Work-ers: The Mediating Effect of Job Stress. J. Hum. Resour. Manag. Res. 2019, 26, 33-55. [CrossRef]

5. Parasuraman, A.; Zeithaml, V.A.; Berry, L.L. SERVQUAL: A Multiple-Item Scale for Measuring Consumer Perceptions of Service Quality. J. Retail. 1988, 64, 12-40.

6. Zeithaml, V.A.; Berry, L.L.; Parasuraman, A. The Behavioral Consequences of Service Quality. J. Mark. 1996, 60, 31. [CrossRef]

7. Bellou, V.; Andronikidis, A.I. Examining organizational climate in Greek hotels from a service quality perspective. Int. J. Contemp. Hosp. Manag. 2009, 21, 294-307. [CrossRef]

8. Bouranta, N.; Chitiris, L.; Paravantis, J. The relationship between internal and external service quality. Int. J. Contemp. Hosp. Manag. 2009, 21, 275-293. [CrossRef]

9. Chang, K.-C. Effect of servicescape on customer behavioral intentions: Moderating roles of service climate and employee engagement. Int. J. Hosp. Manag. 2016, 53, 116-128. [CrossRef]

10. Nguyen, T.K.P.; Ahn, Y.J.; Lee, S.K. Determinants of Hallyu tourism among market segments in Vietnam. J. Artic. Manag. Syst. 2018, 14, 47-66. [CrossRef]

11. Ahn, Y.-J. Recruitment of volunteers connected with sports mega-events: A case study of the PyeongChang 2018 Olympic and Paralympic Winter Games. J. Destin. Mark. Manag. 2018, 8, 194-203. [CrossRef]

12. Fung, C.; Sharma, P.; Wu, Z.; Su, Y. Exploring service climate and employee performance in multicultural service settings. J. Serv. Mark. 2017, 31, 784-798. [CrossRef]

13. Kang, H.J.; Kim, W.G.; Choi, H.-M.; Li, Y. How to fuel employees' prosocial behavior in the hotel service encounter. Int. J. Hosp. Manag. 2020, 84, 102333. [CrossRef]

14. Dienhart, J.R.; Gregoire, M.B.; Downey, R.G.; Knight, P.K. Service orientation of restaurant employees. Int. J. Hosp. Manag. 1992, 11, 331-346. [CrossRef]

15. Schneider, B.; Gunnarson, S.K.; Niles-Jolly, K. Creating the climate and culture of success. Organ. Dyn. 1994, 23, 17-29. [CrossRef]

16. Schneider, B.; White, S.S.; Paul, M.C. Linking service climate and customer perceptions of service quality: Tests of a causal model. J. Appl. Psychol. 1998, 83, 150-163. [CrossRef]

17. Bowen, D.E.; Schneider, B. A Service Climate Synthesis and Future Research Agenda. J. Serv. Res. 2014, 17, 5-22. [CrossRef]

18. Chiang, C.-F.; Hsieh, T.-S. The impacts of perceived organizational support and psychological empowerment on job performance: The mediating effects of organizational citizenship behavior. Int. J. Hosp. Manag. 2012, 31, 180-190. [CrossRef]

19. Davidson, M.C. Does organizational climate add to service quality in hotels? Int. J. Contemp. Hosp. Manag. 2003, 15, 206-213. [CrossRef]

20. Cho, S.; Johanson, M.M. Organizational Citizenship Behavior and Employee Performance: A Moderating Effect of Work Status in Restaurant Employees. J. Hosp. Tour. Res. 2008, 32, 307-326. [CrossRef]

21. Hechanova, M.R.M.; Alampay, R.B.A.; Franco, E.P. Psychological empowerment, job satisfaction and performance among Filipino service workers. Asian J. Soc. Psychol. 2006, 9, 72-78. [CrossRef] 
22. Chathoth, P.K.; Mak, B.; Jauhari, V.; Manaktola, K. Employees' Perceptions of Organizational Trust and Service Climate: A Structural Model Combining Their Effects On Employee Satisfaction. J. Hosp. Tour. Res. 2007, 31, 338-357. [CrossRef]

23. Chiang, F.F.; Birtch, T.A. Reward climate and its impact on service quality orientation and employee attitudes. Int. J. Hosp. Manag. 2011, 30, 3-9. [CrossRef]

24. Choi, C.H.; Kim, T.; Lee, G.; Lee, S.K. Testing the stressor-strain-outcome model of customer-related social stressors in predicting emotional exhaustion, customer orientation and service recovery performance. Int. J. Hosp. Manag. 2014, 36, 272-285. [CrossRef]

25. Chou, S.-F.; Horng, J.-S.; Liu, C.-H.; Gan, B. Explicating restaurant performance: The nature and foundations of sustainable service and organizational environment. Int. J. Hosp. Manag. 2018, 72, 56-66. [CrossRef]

26. He, Y.; Li, W.; Lai, K.K. Service climate, employee commitment and customer satisfaction: Evidence from the Hospitality Industry in China. Int. J. Contemp. Hosp. Manag. 2011, 23, 592-607. [CrossRef]

27. Kang, H.J.; Busser, J. Impact of service climate and psychological capital on employee engagement: The role of organizational hierarchy. Int. J. Hosp. Manag. 2018, 75, 1-9. [CrossRef]

28. Kralj, A.; Solnet, D. Service climate and customer satisfaction in a casino hotel: An exploratory case study. Int. J. Hosp. Manag. 2010, 29, 711-719. [CrossRef]

29. Mokhtaran, M.; Fakharyan, M.; Jalilvand, M.R.; Mohebi, M. The Effect of Service Climate on Perceived Service Value and Behavioral Intentions: The Mediating Role of Service Quality. Asia Pac. J. Tour. Res. 2014, 20, 472-486. [CrossRef]

30. Cha, J.; Borchgrevink, C.P. Service Climate in Restaurants. Int. J. Hosp. Tour. Adm. 2014, 15, 19-37. [CrossRef]

31. Schneider, B. Organizational climates: An essay. Pers. Psychol. 1975, 28, 447-479. [CrossRef]

32. Solnet, D.; Paulsen, N. Service Climate, Employee Identification, and Customer Outcomes in Hotel Property Rebrandings. J. Hosp. Leis. Mark. 2006, 13, 3-27. [CrossRef]

33. Spreitzer, G.M. Psychological, empowerment in the workplace: Dimensions, measurement and validation. Acad. Manag. J. 1995, 38, 1442-1465. [CrossRef]

34. Spreitzer, G.M. Social structural characteristics of psychological empowerment. Acad. Manag. J. 1996, 39, 483-504. [CrossRef]

35. Thomas, K.W.; Velthouse, B.A. Cognitive Elements of Empowerment: An “Interpretive" Model of Intrinsic Task Motivation. Acad. Manag. Rev. 1990, 15, 666. [CrossRef]

36. Conger, J.A.; Kanungo, R.N. The Empowerment Process: Integrating Theory and Practice. Acad. Manag. Rev. 1988, 13, 471-482. [CrossRef]

37. Ashforth, B.E. The experience of powerlessness in organizations. Organ. Behav. Hum. Decis. Process. 1989, 43, 207-242. [CrossRef]

38. Fulford, M.D.; Enz, C.A. The Impact of Empowerment on Service Employees. J. Manag. Issues 1995, 7, 161-175.

39. Orlowski, M.; Bufquin, D.; Nalley, M.E. The Influence of Social Perceptions on Restaurant Employee Work Engagement and Extra-Role Customer Service Behavior: A Moderated Mediation Model. Cornell Hosp. Q. 2020. [CrossRef]

40. Organ, D.W. Organizational Citizenship Behavior: The Good Soldier Syndrome; Organizational Citizenship Be-Havior: The Good Soldier Syndrome; Lexington Books: Lexington, MA, UK, 1988; ISBN 978-0-669-11788-2.

41. Bettencourt, L.A.; Gwinner, K.P.; Meuter, M.L. A comparison of attitude, personality, and knowledge predictors of service-oriented organizational citizenship behaviors. J. Appl. Psychol. 2001, 86, 29-41. [CrossRef]

42. Organ, D.W.; Konovsky, M. Cognitive versus affective determinants of organizational citizenship behavior. J. Appl. Psychol. 1989, 74, 157-164. [CrossRef]

43. Podsakoff, P.M.; MacKenzie, S.B. Impact of Organizational Citizenship Behavior on Organizational Performance: A Review and Suggestion for Future Research. Hum. Perform. 1997, 10, 133-151. [CrossRef]

44. Van Dyne, L.; Graham, J.W.; Dienesch, R.M. Organizational citizenship behavior: Construct redefinition, measurement, and validation. Acad. Manag. J. 1994, 37, 765-802. [CrossRef]

45. Chow, C.W.; Lai, J.Y.; Loi, R. Motivation of travel agents' customer service behavior and organizational citizenship behavior: The role of leader-member exchange and internal marketing orientation. Tour. Manag. 2015, 48, 362-369. [CrossRef]

46. Hwang, K.; Lee, B. Pride, mindfulness, public self-awareness, affective satisfaction, and customer citizenship behaviour among green restaurant customers. Int. J. Hosp. Manag. 2019, 83, 169-179. [CrossRef]

47. Nguyen, H.; Groth, M.; Walsh, G.; Hennig-Thurau, T. The Impact of Service Scripts on Customer Citizenship Behavior and the Moderating Role of Employee Customer Orientation. Psychol. Mark. 2014, 31, 1096-1109. [CrossRef]

48. Raub, S. Does bureaucracy kill individual initiative? The impact of structure on organizational citizenship behavior in the hospitality industry. Int. J. Hosp. Manag. 2008, 27, 179-186. [CrossRef]

49. Tang, T.-W.; Tang, Y.-Y. Promoting service-oriented organizational citizenship behaviors in hotels: The role of high-performance human resource practices and organizational social climates. Int. J. Hosp. Manag. 2012, 31, 885-895. [CrossRef]

50. Stamper, C.L.; Van Dyne, L. Work status and organizational citizenship behavior: A field study of restaurant employees. J. Organ. Behav. 2001, 22, 517-536. [CrossRef]

51. Stamper, C. Organizational citizenship: A comparison between part-time and full-time service employees. Cornell Hotel. Restaur. Adm. Q. 2003, 44, 33-42. [CrossRef]

52. Hennig-Thurau, T. Customer orientation of service employees: Its Impact on Customer Satisfaction, Com-mitment, and Retention. Int. J. Serv. Ind. Manag. 2004, 15, 460-478. [CrossRef]

53. Bettencourt, L.A.; Brown, S.W. Contact employees: Relationships among workplace fairness, job satisfaction and prosocial service behaviors. J. Retail. 1997, 73, 39-61. [CrossRef] 
54. Kim, M.J. The Republic of Korea's Employment Permit System (EPS): Background and Rapid Assessment. EPS 2015, 50. [CrossRef]

55. Tsaur, S.-H.; Lin, Y.-C. Promoting service quality in tourist hotels: The role of HRM practices and service behavior. Tour. Manag. 2004, 25, 471-481. [CrossRef]

56. Tsaur, S.-H.; Wang, C.-H.; Yen, C.-H.; Liu, Y.-C. Job standardization and service quality: The mediating role of prosocial service behaviors. Int. J. Hosp. Manag. 2014, 40, 130-138. [CrossRef]

57. Heckathorn, D.D. Respondent-Driven Sampling: A New Approach to the Study of Hidden Populations. Soc. Probl. 1997, 44, 174-199. [CrossRef]

58. Anderson, J.C.; Gerbing, D.W. Structural equation modeling in practice: A review and recommended two-step approach. Psychol. Bull. 1988, 103, 411-423. [CrossRef]

59. Byrne, B.M. Structural Equation Modeling With Lisrel, Prelis, and Simplis: Basic Concepts, Applications, and Programming, 1st ed.; Psychology Press: Mahwah, NJ, USA, 1998; ISBN 978-0-8058-2924-2.

60. Byrne, B.M. Structural Equation Modeling with AMOS: Basic Concepts Applications and Programming, 2nd ed.; Routledge: New York, NY, USA, 2009; ISBN 978-0-8058-6373-4.

61. Hair, J.F.; Black, W.C.; Babin, B.J.; Anderson, R.E. Multivariate Data Analysis, 7th ed.; Pearson: Upper Saddle River, NJ, USA, 2009; ISBN 978-0-13-813263-7.

62. Bagozzi, R.P.; Yi, Y. On the evaluation of structural equation models. J. Acad. Mark. Sci. 1988, 16, 74-94. [CrossRef]

63. Fornell, C.; Larcker, D.F. Evaluating Structural Equation Models with Unobservable Variables and Measurement Error. J. Mark. Res. 1981, 18, 39. [CrossRef]

64. Ahn, Y.-J.; Lee, B.C.; Lee, S.K. Analysis of Korean millennials' travel expenditure patterns: An almost ideal demand system approach. Asia Pac. J. Tour. Res. 2019, 25, 3-14. [CrossRef] 